\title{
Estrogen responsiveness of bone formation in vitro and altered bone phenotype in aged estrogen receptor- $\alpha$-deficient male and female mice
}

\author{
Vilhelmiina Parikka ${ }^{1,2}$, ZhiQi Peng ${ }^{1}$, Teuvo Hentunen ${ }^{1}$, Juha Risteli ${ }^{3,4}$, Teresa Elo ${ }^{1}$, H Kalervo Väänänen ${ }^{1}$ and \\ Pirkko Härkönen ${ }^{1,5}$ \\ ${ }^{1}$ Department of Anatomy and Medicity Research Laboratory, University of Turku, FIN-20700 Turku, Finland, ${ }^{2}$ Turku Graduate School of Biomedical \\ Sciences, Turku, Finland, ${ }^{3}$ Department of Clinical Chemistry, University of Oulu, FIN-90014 Oulu, Finland, ${ }^{4}$ Department of Clinical Chemistry, \\ University of Kuopio, FIN-70211 Kuopio, Finland, ${ }^{5}$ Department of Laboratory Medicine, Tumor Biology, University Hospital MAS, Lund University, \\ S-21771 Malmö, Sweden
}

(Correspondence should be addressed to V Parikka, Clinical Research Center, PL5000, FIN-90014 University of Oulu, Finland; Email: vilpar@utu.fi)

\begin{abstract}
Objective: Although the beneficial effects of estrogen on bone are well known, the roles of estrogen receptors (ERs) in mediating these effects are not fully understood.

Methods: To study the effects of long-term ER $\alpha$ deficiency, bone phenotype was studied in aged ER $\alpha$ knockout (ERKO) mice. In addition, ERKO osteoclasts and osteoblasts were cultured in vitro.

Design and results: Histomorphometric analysis showed that the trabecular bone volume and thickness were significantly increased and the rate of bone formation enhanced in both male and female ERKO mice in comparison to the wild-type animals. In ERKO males, however, the bones were thinner and their maximal bending strengths decreased. Consistent with previous reports, the bones of knockout mice, especially of female mice, were shorter than those of wild-type mice. In addition, the growth plates were totally absent in the tibiae of aged ERKO females, whereas the growth plate cartilages were detectable in wild-type females as well as in all the males. Analysis of cultured bone marrow cells from 10- to 12-week-old mice demonstrated that $17 \beta$-estradiol could stimulate osteoblastic differentiation of bone marrow cells derived from ERKO mice relatively to the same extent as those derived from wild-type mice. This was demonstrated by increases in synthesis of type I collagen, activity of alkaline phosphatase and accumulation of calcium in cultures. Total protein content was, however, reduced in ERKO osteoblast cultures.

Conclusions: These results show altered bone phenotype in ERKO mice and demonstrate the stimulatory effect of estrogen on osteoblasts even in the absence of full-length ER $\alpha$.
\end{abstract}

European Journal of Endocrinology 152 301-314

\section{Introduction}

Estrogens are key regulators of bone growth, maturation and metabolism both in females and males. In menopause, decreased estrogen leads to an increased rate of remodeling, which is caused by an imbalance between bone resorption by osteoclasts and new bone formation by osteoblasts. This condition is associated with a decrease in bone mineral density leading to an increased fracture risk. Lack of estrogen in aromatase deficiency (due to mutations in the cytochrome P450 subfamily XIX (CYP19) gene) results in decreased bone mineral density, delayed epiphyseal closure and tall stature in affected humans $(1,2)$. Therapeutic responses of these patients to estrogen, but not to androgen therapy, have been demonstrated (2). Bone loss was also demonstrated experimentally in aromatase knockout mice $(3,4)$ and in the mice treated with aromatase inhibitors (5). Male, but not female, aromatase knockout mice have, however, a shortened femur length (3), which is opposite to what was found in the aromatase-deficient humans.

At cellular level 17ß-estradiol (E2), a biologically active form of estrogen, is known to stimulate osteogenic activity $(6,7)$ and to have anti-apoptotic effects in osteoblasts (7-9). It is also well demonstrated that osteoclast formation from mononuclear hematopoietic stem cells is inhibited by E2 treatment $(10,11)$. In addition, we have recently shown that bone resorption activity of mature osteoclasts is inhibited by E2, which leads to reduced depth of resorption lacunae (12). Most estrogen effects are thought to be mediated via nuclear estrogen receptors alpha $(E R \alpha)$ and beta $(\mathrm{ER} \beta)$, although non-receptor-mediated effects have also been suggested. Both ER $\alpha$ and ER $\beta$ are expressed in bone marrow cells $(13,14)$, and in osteoblasts $(15-17)$. Data on ER expression in osteoclasts remains 
conflicting. ERs have been reported to be expressed in osteoclasts $(18,19)$ and in their mononuclear precursors $(20,21)$ whereas some reports claim that they are not expressed in osteoclastic cells at all (22).

Estrogen resistance due to a disruptive mutation in the ER $\alpha$ gene leads to an altered bone phenotype as shown by a 28 -year-old man who has a tall stature, an incomplete epiphyseal closure and increased bone turnover rate (23). In the in vitro cultures, mesenchymal cells of this patient were capable of differentiating to bone-forming osteoblasts, which secreted high levels of insulin-like growth factor-I (IGF-I) and interleukin-6 (24).

Transgenic animal models have provided excellent tools for studies on the role of ERs in bone tissue. These studies have emphasized a central role of ER $\alpha$ in bone physiology $(25,26) . \mathrm{ER} \alpha$ deficiency (27) leads to marked consequences in bone as in various other tissues (28). Bone phenotype in ER $\alpha$ knockout (ERKO) mice, however, clearly differs from that in ovariectomized animals (29). Trabecular bone mineral density, for example, has been demonstrated to be increased in ERKO animals (30-32). Studies on ERKO mice have also shown that estrogen does not have a stimulatory effect on cancellous bone formation in male knockout mice (33). It also fails to prevent orchidectomy-induced bone loss in male ERKO animals (31, 34). In a recent study using another ER $\alpha$-deficient mouse line $\left(\mathrm{ER} \alpha^{-/-}\right)$, E2 could partially protect female $\mathrm{ER} \alpha^{-\gamma_{-}}$mice against ovariectomy-induced bone loss, but no response to E2 was found in orchidectomized male $\mathrm{ER} \alpha^{-/-}$mice (26). Analysis of ERKO mice has also demonstrated that bone adaptation to mechanical loading requires $\operatorname{ER} \alpha$ (35).

In this study we used aged (over 1 year old) female and male $\mathrm{ER} \alpha$ knockout mice to analyse the effects of longterm ER $\alpha$ deficiency on bone. The long bones (tibiae and femora) were analysed by peripheral quantitative computed tomography, histomorphometry and strength measurements. We also cultured bone cells (osteoblasts and osteoclasts) in in vitro conditions to learn whether the presence of full-length ER $\alpha$ is needed for normal cell growth and function. The capacity of bone marrow cells of the ERKO vs wild-type mice to differentiate to osteoblasts and to respond to estrogen was studied in the cultures. We demonstrate in this work that estrogen can stimulate osteoblastic differentiation and bone formation in vitro in bone marrow cultures of ERKO mice in the absence of full-length ER $\alpha$.

\section{Materials and methods}

\section{Animals}

ERKO mice with a $\mathrm{C} 57 \mathrm{Bl} / 6$ genetic background generated as previously described (27) were a gift from Dr Kenneth Korach (National Institute of Environmental Health Sciences, National Institutes of Health,
Research Triangle Park, North Carolina, USA). They were transferred to and bred in the animal facilities of the University of Turku. PCR-based genotyping was performed on DNA extracted from mouse tail tips. Primers for determination of the wild-type ER gene were CGGTCTACGGCCAGTCGGGCACC and GTAGAAGGCGGGAGGGCCGGTGTC (27). Primers for the knockout gene were TGTGGCCGGCTGGGTGTG and GGCGCTGGGCTCGTTCTC (36).

Mice were given standard commercial food (RM1, SDS Ltd, Witham, Essex, UK) and water ad libitum. The animals were maintained in accordance with the guidelines of the Turku University Ethical Committee for the use and care of experimental animals. Fiftytwo ERKO or wild-type mice (over 1 year old) were used for histomorphometric analysis and peripheral quantitative computed tomography (pQCT). In order to study bone formation in vivo, mice were given intraperitoneal injections of tetracycline hydrochloride ( $15 \mathrm{mg} / \mathrm{kg}$; Sigma) and calcein to label bone-forming surfaces $(15 \mathrm{mg} / \mathrm{kg}$; Sigma) at 17 and 3 days respectively before killing the animals.

\section{PQCT}

The mice were killed by $\mathrm{CO}_{2}$ asphyxiation. Right tibiae and femora were excised and stored at $-20^{\circ} \mathrm{C}$. For analysis, they were first thawed at room temperature for $1 \mathrm{~h}$. After cleaning up soft tissues, the bone was fixed in a plastic tube ( $8 \mathrm{~mm}$ diameter) with a spring and scanned by pQCT (XCT 540; Stratec, Norland Medical Systems, Pforzheim, Germany). For tibial measurements, the reference line was placed at the proximal end of tibia. Three cross-sections, with a $0.5 \mathrm{~mm}$ distance between each other, were measured $1.5 \mathrm{~mm}$ from the reference line. Two sections with a distance of $0.5 \mathrm{~mm}, 3 \mathrm{~mm}$ above the reference line in the tibiofibular junction were also measured. In femur, three sections were measured starting $1.8 \mathrm{~mm}$ from the distal end of the femur, and another two sections were measured $5 \mathrm{~mm}$ from the distal end of the femur. Special Software version 5.40 was used for the images of each section with a voxel size of $0.10 \mathrm{~mm}$. A standardized analysis (peel mode 2, cort mode 1, contour mode 1 , threshold $0.25 \mathrm{~g} / \mathrm{cm}^{3}$ for trabecular bone and $0.71 \mathrm{~g} / \mathrm{cm}^{3}$ for cortical bone) was applied.

\section{Mechanical testing of bones and determination of ash weight}

After measuring the bone density and length, the maximal bending load was measured from the right tibiae and the right femora as described previously (37). The lateral surface of the tibia or posterior surface of the femur was put on the supports. The span of the supports was $8 \mathrm{~mm}$. Finally, the fractured tibiae and femora were burned at $550{ }^{\circ} \mathrm{C}$ for $20 \mathrm{~h}$ to get the individual bone ash weight. 


\section{Bone histomorphometry}

Left tibiae and femora were fixed in $40 \%$ ethanol. After dehydration, samples were embedded into methylmethacrylate as described previously (37). Longitudinal undecalcified sections ( 4 and $8 \mu \mathrm{m}$ thick) were prepared from tibia. Cross-sections of $80 \mu \mathrm{m}$ were harvested $6 \mathrm{~mm}$ above the distal end of the femur by a lowspeed saw. Sections of $4 \mu \mathrm{m}$ thickness were stained using the Masson-Goldner trichrome method and the histomorphometric data of the trabecular bone in the proximal tibia were measured in a field of $0.75 \mathrm{~mm}^{2}$ below the growth plate and locating the middle of the section. Because the growth plate disappeared in female ERKO mice, the measured field was $0.9 \mathrm{~mm}$ below the proximal end of the tibia. Unstained sections of 8 and $80 \mu \mathrm{m}$ thickness were used to measure the dynamic parameters of bone formation. All measurements and analyses were performed according to the report of the ASBMR Histomorphometry Nomenclature Committee (38), and using an Olympus microscope combined to a computer with the OsteoMeasure $\mathrm{V}$ 2.31-program (OsteoMetrics Inc., Atlanta, GA, USA).

\section{Hormone measurements}

Serum samples were collected by cardiac puncture, separated by centrifugation and stored at $-20^{\circ} \mathrm{C}$ until used for testosterone and E2 measurements. Testosterone levels were measured by DELFIA after diethyl ether extraction, and the concentrations of E2 were measured using commercial RIA kits (Wallac Delfia; Perkin Elmer, Turku, Finland) as described previously (39). Testosterone levels were measured from serum samples of the same animals as were used for histomorphometric analysis. The amount of serum collected was not sufficient for estradiol measurements in all the animals. Thus, serum was collected for estradiol analysis also from other aged ERKO and wild-type animals. Estradiol data are a combination of original samples (from 12 mice) and new serum samples (from 21 mice).

\section{Cell culture reagents}

All cell culture reagents, if not otherwise mentioned, were obtained from Invitrogen. E2 (Sigma) and ICI 182,780 (a gift from Dr A E Wakeling; Zeneca Pharmaceuticals, Macclesfield, UK) were dissolved in ethanol as a $1 \mathrm{mM}$ stock solution. Peroxidase-conjugated wheat germ agglutinin (WGA)-lectin, Hoechst 33 258, leukocyte acid phosphatase kit 387-A, dexamethasone, $\beta$-glycerophosphate and ascorbic acid 2-phosphate were purchased from Sigma.

Recombinant human bone morphogenetic protein-4 (BMP-4) was from R\&D Systems Inc. (Minneapolis, MN, USA).

\section{Osteoclast cultures}

A mixed mouse bone cell population was cultured on bovine bone slices as described previously $(40,41)$. Briefly, 3-day-old mouse pups were killed by cervical dislocation and osteoclasts and other cells were scraped from tibiae, femora and humeri and allowed to attach to bone slices for $30 \mathrm{~min}$, after which the non-attached cells were washed away. The cells on bone slices were cultured for 3 days in phenol-red-free minimal essential medium (MEM) $\alpha$ medium buffered with $20 \mathrm{mM}$ HEPES and containing $100 \mathrm{IU}$ penicillin $/ \mathrm{ml}, 100 \mu \mathrm{g}$ streptomycin $/ \mathrm{ml}$ and $10 \%$ heat-inactivated fetal calf serum (FCS) in a humified atmosphere of $95 \%$ air and 5\% $\mathrm{CO}_{2}$ at $37^{\circ} \mathrm{C}$. After the culture period, bone slices with cells were fixed in 3\% paraformaldehyde for 15 min. Cells were stained with tartrate-resistant acid phosphatase (TRACP) to detect osteoclasts, and with the DNA-binding fluorochrome Hoechst 33258 to visualize all the nuclei. Multinucleated TRACP-positive cells were counted as osteoclasts and the average number of nuclei per osteoclast was quantified. In addition, bone slices were stained with TRITC-conjugated phalloidin (Sigma) to study actin ring formation in cultures (42).

After the cell parameters and the number of actin rings were determined, all cells were removed from bone slices. Resorption lacunae were visualized by WGA-lectin according to Selander and co-workers (43). Briefly, bone slices were incubated with peroxidase-conjugated WGA-lectin for $40 \mathrm{~min}$, after which diaminobenzidine solution was added to the bone slices for $10 \mathrm{~min}$. The number of resorption pits was quantitated under a Leica DMRB microscope (Leica, Wetzlar, Germany).

\section{Osteoblast cultures}

Osteoblasts were cultured in phenol-red-free MEM $\alpha$ medium supplemented with $10 \%$ FCS, $20 \mathrm{mM}$ HEPES, $10 \mathrm{nM}$ dexamethasone, ascorbic acid $(50 \mathrm{mg} / \mathrm{l})$, $10 \mathrm{mM}$ sodium $\beta$-glycerophosphate and antibiotics. Bone marrow cells were obtained from the tibiae and femora of 10- to 12-week-old mice as previously described (6). Animals were killed by cervical dislocation, after which bones were removed and the soft tissues detached aseptically. Metaphyses from both ends were resected and bone marrow cells collected by flushing the diaphysis with warm culture medium repetitively. Nucleated cells were counted with a hemocytometer, and cells were plated in tissue culture flasks (Nunc, Roskilde, Denmark) at a density of $10^{6} \mathrm{cells} / \mathrm{cm}^{2}$, and cultured for 7 days by replacing the medium after 3 days. On day 7 , cells were washed with warm PBS and adherent cells were detached into the medium using a cell scraper. After centrifugation, cells were counted and plated in 24-well plates at a density of 10000 cells/well. All 
these subcultures were made in duplicate, since alkaline phosphatase (ALP) activity and calcium content of culture were measured from different cell lysates. ALP activity was measured on subculture day 9 (day 16) and calcium on subculture day 14 (day 21). Nterminal propeptide of type-I procollagen (PINP) was measured from culture medium on subculture days 3 , 6 and 9.

\section{Assay of the activity of cellular ALP}

After the culture period, mouse bone marrow cells were washed twice with warm PBS, and extracted into $200 \mu \mathrm{l}$ assay buffer containing $50 \mathrm{mM}$ Tris $-\mathrm{HCl}$, $0.1 \%$ Triton $\mathrm{X}-100$ and $0.9 \% \mathrm{NaCl}(\mathrm{pH} 7.6)$. After adding the buffer solution to each well, culture plates were frozen. After thawing, cell lysate was rinsed out and enzyme activity measured using $0.1 \mathrm{M}$ 4-p-nitrophenylphosphate (Sigma) as substrate. Absorbance was read at $405 \mathrm{~nm}$ in a plate reader (Victor 2, Wallac, Turku, Finland). Each sample was measured in duplicate. In parallel, the protein contents of the wells were determined by BIO-RAD protein assay (BioRad). Specific activity of ALP was expressed as absorbance per protein $(\mathrm{mg} / \mathrm{ml})$.

\section{Determination of calcium content}

Calcium content in the mouse bone marrow cell cultures was determined after 14 days in subculture (21 days in culture). Cells on 24-well plates were washed two times with $\mathrm{Ca}^{2+}$ - and $\mathrm{Mg}^{2+}$-free PBS and incubated overnight in $200 \mu \mathrm{l} 0.6 \mathrm{~N} \mathrm{HCl}$ at $+4{ }^{\circ} \mathrm{C}$. Extracts were complexed with o-cresol-phthalein-complexon (Roche) and the colorimetric reaction was read at $570 \mathrm{~nm}$ in a plate reader. Calcium contents were determined by comparison with a calibrated standard (Roche).

\section{RIA for mouse PINP}

PINP was analysed as follows. A synthetic peptide derived from the aminoterminal propeptide of the mouse $\alpha 1$-prochain of type I collagen was manufactured by the Neosystems Laboratoire (Strasbourg, France). The sequence of eight amino acids from the aminoterminal end of the propeptide, QEDIPEVS, was selected and a YC-residue was added to the carboxyterminal end to enable iodination. For polyclonal antibody production, the peptide was conjugated to $140 \mu \mathrm{l}$ keyhole limpet and injected intradermally with Freund's adjuvant into two New Zealand white rabbits. Boosters were given at 3-week intervals until a good titer was reached.

The synthetic peptide was labeled with ${ }^{125} \mathrm{I}$ by the chloramine $\mathrm{T}$ method. The labeled peptide was separated from free iodine with the disposable Sep-Pak C18 reversed-phase cartridges (Waters, Milford, MA, USA) by elution with $11 \mathrm{ml}$ of $0.1 \mathrm{~mol} / \mathrm{l}$ acetic acid and
$3 \mathrm{ml}$ of $50 \%$ 2-propanol, $0.1 \mathrm{~mol} / \mathrm{l}$ acetic acid. In the RIA, $100 \mu \mathrm{l}$ aliquots of known standards based on the synthetic peptide or unknown samples were incubated with $200 \mu \mathrm{l}$ tracer solution $(\sim 50000$ counts $/ \mathrm{min})$ and $200 \mu \mathrm{l}$ diluted antiserum for $2 \mathrm{~h}$ at $37^{\circ} \mathrm{C}$. Then $500 \mu \mathrm{l}$ of a PEG second antibody were added and the incubation continued at $+4^{\circ} \mathrm{C}$ for $30 \mathrm{~min}$. The samples were centrifuged at 3000 r.p.m. for $30 \mathrm{~min}$ at $+4{ }^{\circ} \mathrm{C}$ and the supernatants discarded. The radioactivity of the samples was counted with a 1470 Wizard counter (Wallac, Turku, Finland). The specificity of the antibody was assessed by testing the binding of a synthetic peptide of the mouse $\alpha 1$ (III) collagen. Medium for RIA was collected from osteoblast cultures at subculture days 3, 6 and 9 (culture days 10, 13 and 16).

\section{RNA isolation and RT-PCR}

Mice were killed using $\mathrm{CO}_{2}$, tissue samples were rapidly excised and frozen in liquid nitrogen. Bone marrow samples were taken from vertically split femurs and tibias with a needle. Total RNA was isolated from tissue samples by the single-step method (44). Complementary DNA synthesis was performed from 1-2 $\mu \mathrm{g}$ total RNA using 90 pmol oligo d(T)18 (New England Biolabs Inc., Beverly, MA, USA), 1 nM dNTPs (Finnzymes, Espoo, Finland), 20 units of RNase inhibitor (Promega) and 10 units of avian myeloblastosis virus (AMV) reverse transcriptase (Finnzymes) in the final volume of $20 \mu \mathrm{l}$. Sequences of the primers used for estrogen receptor-related receptor- $\alpha(\operatorname{ERR} \alpha)$ PCR were ERR $\alpha$ F: 5' CCAGGCTTCTCCTCACTGTC 3' (exons 5-6) and ERR $\alpha$ R: 5' GCCCCCTCTTCATCTAGGAC 3' (exon 6) resulting in an amplification product of $153 \mathrm{bp}$. Sequences for ER $\beta$ PCR were ER $\beta F$ : $5^{\prime}$ GAAGCTGGCTGACAAGGAAC 3' (exon 3) and ERßR: 5' AACGAGGTCTGGAGCAAGA $3^{\prime}$ (exon 4) resulting in an amplification product of $187 \mathrm{bp}$. Sequences for ERR $\gamma$ PCR were $5^{\prime}$ GATGAGCCTCCTCCAGAGTG $3^{\prime}$ and $5^{\prime}$ TGCACAGCTTCCACATCTTC $3^{\prime}$ resulting in an amplification product of $275 \mathrm{bp}$. Amplification parameters used for $\mathrm{ERR} \alpha$ PCRs were: denaturation at $94^{\circ} \mathrm{C}$ for $1 \mathrm{~min}$, annealing at $61^{\circ} \mathrm{C}$ for $1 \mathrm{~min}$ and extension at $72{ }^{\circ} \mathrm{C}$, for 35 cycles. For ER $\beta$ and ERR $\gamma$ PCR, the conditions were the same except for an annealing temperature of $58{ }^{\circ} \mathrm{C}$ and a cycle number of 40 for ER $\beta$ and an annealing temperature of $60^{\circ} \mathrm{C}$ for ERR $\gamma$. PCR products $(20 \mu \mathrm{l})$ and $100 \mathrm{bp}$ ladder (New England Biolabs) were run on a $1.5 \%$ agarose gel stained with ethidium bromide.

\section{Statistical analysis}

The statistical significance of differences between treatment groups was determined using ANOVA and the unpaired Student's $t$-test was used to compare means between groups. A $P$ value of less than 0.05 was considered significant. 


\section{Results}

\section{Bone ash weight and bone length}

Gross bone phenotype in old ERKO mice (average age 14 months) in comparison to wild-type controls was studied by determining bone ash weights and measuring bone lengths. As previously reported in younger mice (30), body weight was significantly increased in aged ERKO females compared with wild-type animals (Fig. 1A). Ash weights of tibiae were also higher in ERKO females (Fig. 1A). Interestingly, ash weights of tibiae and femora were not increased, but rather decreased, in ERKO males. The lengths of tibiae, femora and lumbar vertebrae (L1-L6) were measured and all the bones were shorter in ERKO males, and even more so in ERKO females (Fig. 1B).
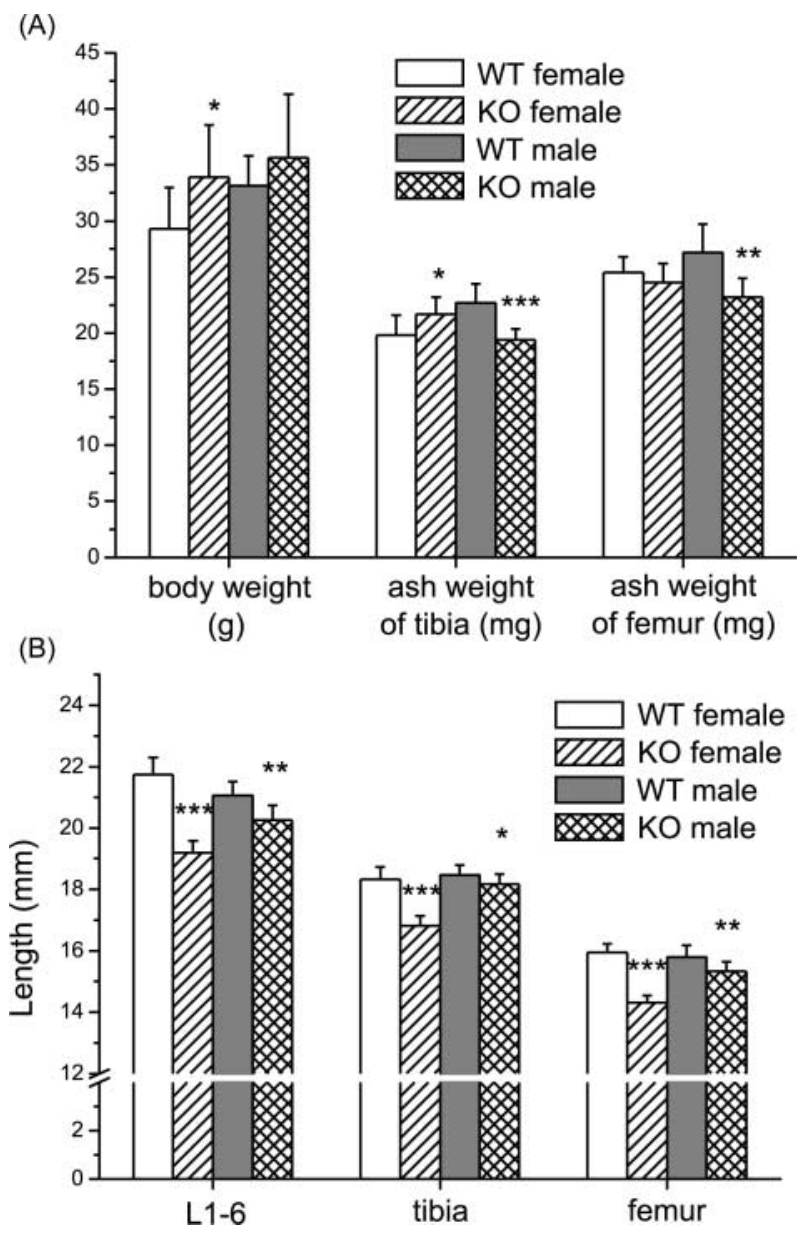

Figure 1 (A) Total body weight and ash weight of tibia and femur. (B) Length of lumbar vertebrae (L1-L6), tibia and femur. Values are presented as means \pm S.D. The $P$ values from Student's $t$-test between wild-type and ERKO females, or wild-type and ERKO males, are shown as asterisks $\left({ }^{\star} P<0.05,{ }^{\star \star} P<0.01\right.$,

$\left.{ }^{* \star \star} P<0.001\right)$. The number of animals per group was: 11 (WT female), 14 (KO female), 16 (WT male) and 13 (KO male). WT, wild-type; KO, knockout.

\section{pQCT measurements}

Bone mineral density (BMD) was measured at the proximal tibia and distal femur of mice (Table 1). Both female and male ERKO mice showed an increased density of trabecular bone. The increase was more pronounced in females, trabecular BMD being even 97\% (tibia) or $111 \%$ (femur) higher than in wild-type mice. Cortical bone density was slightly increased in the tibial, but not in femoral, shaft of ERKO females. The cortical BMD in ERKO males was similar to that of wild-type males. The tissue area of the proximal tibia and distal femur was markedly reduced in male ERKO mice, but in females it was similar to wild-type mice. Tissue area of bone shafts was significantly reduced (meaning thinner bones) in tibiae of both sexes of ERKO mice and in femora of male ERKO animals compared with wildtype animals. Despite decreased tissue area in tibial shafts, cortical bone area was even increased in tibiae and femora of female ERKO mice suggesting a narrowed bone marrow cavity. In contrast, cortical bone area was decreased in tibiae of ERKO male mice. The polar moment of inertia was significantly higher in the femoral shaft of ERKO females, but it was reduced in the long bone shafts of ERKO males when compared with the wild-type animals (Fig. 2A). This is in agreement with the results of maximal bending strengths (Fig. 2B). Femora of ERKO females had a higher maximal bending strength, whereas bones of ERKO males had a reduced bending strength compared with the controls.

\section{Bone histomorphometry}

The left tibia and the femur were used for the histomorphometric analysis. Longitudinal bone sections show the distribution of trabecular bone at the proximal tibia of wild-type and ERKO animals (Fig. 3A). They also demonstrate an increased amount of trabecular bone in both female and male ERKO mice (Fig. 3A). The most conspicuous finding was the total disappearance of the growth plates in aged female ERKO mice whereas they were still open in wild-type females as well as in wild-type and ERKO males. This observation is in accordance with reduced bone lengths in female knockout mice. Histomorphometric analysis of the proximal tibia confirmed that trabecular bone volume (TBV) and trabecular thickness (Tb.Th) were significantly elevated in ERKO females and males (Fig. 3B). The number of osteoclasts on the trabecular bone surface was decreased in ERKO females vs wild-type females (Fig. 3C).

The mineral apposition rate at the proximal tibia was higher in ERKO females and males compared with their wild-type controls (Table 2). Of other parameters for new bone formation only bone formation rate per trabecular bone surface (BFR/BS) and BFR per bone tissue volume (TV) showed statistically significant differences between wild-type and ERKO mice and this was demonstrated 
Table 1 pQCT analysis of tibia and femur in wild-type and ERKO mice.

\begin{tabular}{|c|c|c|c|c|}
\hline & WT female & ERKO female & WT male & ERKO male \\
\hline \multicolumn{5}{|c|}{ Trabecular density $\left(\mathrm{mg} / \mathrm{cm}^{3}\right)$} \\
\hline Tibia & $77 \pm 10.8$ & $152 \pm 24.2^{\star \star *}$ & $147 \pm 27.8$ & $204 \pm 31.2^{\star \star \star}$ \\
\hline Femur & $71 \pm 11.3$ & $150 \pm 23.5^{\star \star \star}$ & $160 \pm 23.7$ & $189 \pm 32.0^{*}$ \\
\hline \multicolumn{5}{|c|}{ Cortical density $\left(\mathrm{mg} / \mathrm{cm}^{3}\right)$} \\
\hline Tibia & $1089 \pm 41$ & $1178 \pm 100.2^{*}$ & $1096 \pm 28.7$ & $1085 \pm 23.4$ \\
\hline Femur & $1033 \pm 55$ & $1049 \pm 39$ & $1006 \pm 31$ & $1024 \pm 41$ \\
\hline \multicolumn{5}{|c|}{ Tissue area $\left(\mathrm{mm}^{2}\right)$} \\
\hline Proximal tibia & $2.56 \pm 0.33$ & $2.67 \pm 0.28$ & $2.72 \pm 0.33$ & $2.23 \pm 0.27^{\star \star \star}$ \\
\hline Distal femur & $3.42 \pm 0.35$ & $3.42 \pm 0.23$ & $3.62 \pm 0.28$ & $3.10 \pm 0.27^{\star \star \star}$ \\
\hline \multicolumn{5}{|c|}{ Tissue area of bone shaft $\left(\mathrm{mm}^{2}\right)$} \\
\hline Tibia & $1.53 \pm 0.15$ & $1.35 \pm 0.07^{* *}$ & $1.63 \pm 0.15$ & $1.35 \pm 0.09^{\star * *}$ \\
\hline Femur & $2.33 \pm 0.23$ & $2.45 \pm 0.22$ & $2.42 \pm 0.19$ & $2.12 \pm 0.16^{\star \star \star}$ \\
\hline \multicolumn{5}{|c|}{ Cortical bone area $\left(\mathrm{mm}^{2}\right)$} \\
\hline Tibia & $0.71 \pm 0.06$ & $0.80 \pm 0.08^{* *}$ & $0.77 \pm 0.06$ & $0.66 \pm 0.04^{\star \star \star}$ \\
\hline Femur & $0.82 \pm 0.08$ & $0.94 \pm 0.11^{\star *}$ & $0.84 \pm 0.06$ & $0.81 \pm 0.07$ \\
\hline
\end{tabular}

Bone mineral density of trabecular and cortical bone, tissue areas (T.Ar) and cortical bone areas (Ct.Ar) are presented. Data are expressed as means \pm S.D. The $P$ values from Student's $t$-test between wild-type (WT) and ERKO females and wild-type and ERKO males are shown as asterisks ${ }^{\star} P<0.05$, $\left.{ }^{* \star} P<0.01,{ }^{\star * *} P<0.001\right)$.
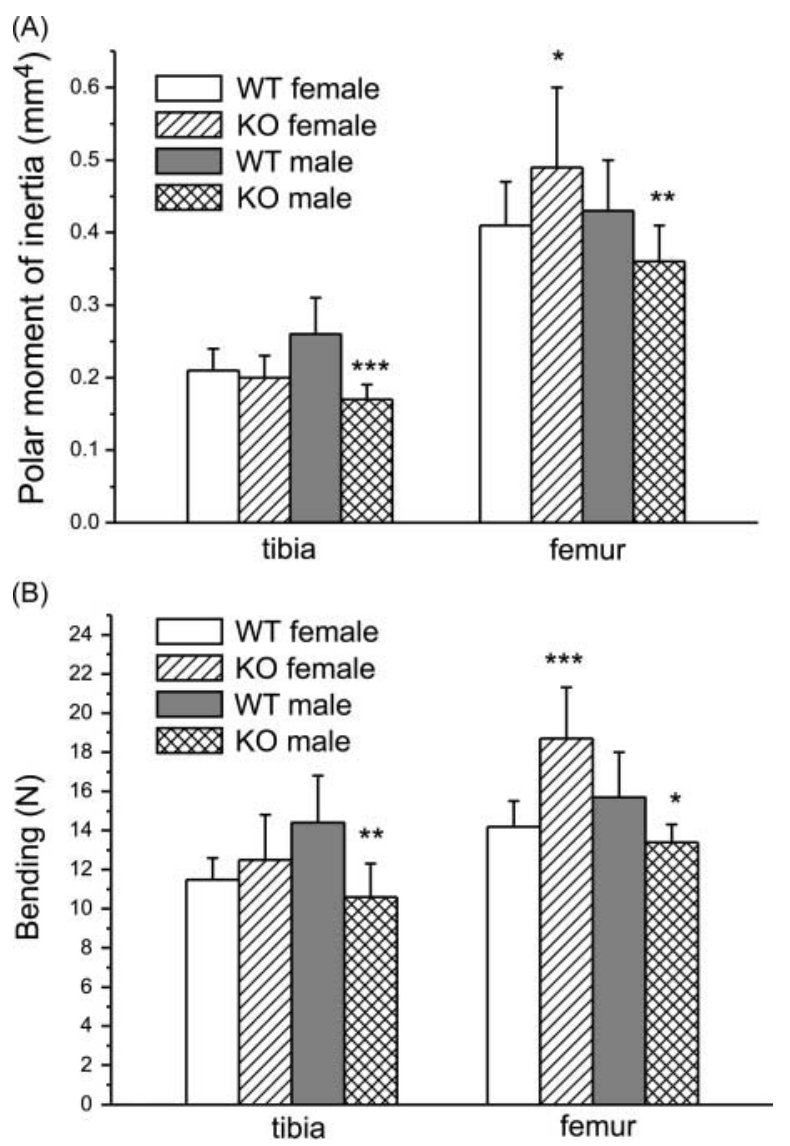

Figure 2 Maximal bending strength for tibia and femur. Values are presented as means \pm S.D. The $P$ values between wild-type and knockout animals are shown as asterisks $\left({ }^{\star} P<0.05\right.$, $\left.{ }^{\star \star} P<0.01,{ }^{\star \star \star} P<0.001\right)$. Numbers per group are the same as for Fig. 1.

only in females. Bone formation at periosteal and endosteal surfaces of the bone was studied by measuring the fluorescent labels from the cross-sections of the femoral shaft. BFR/BS was significantly increased at the periosteum, but decreased at the endocortical surface of male ERKO mice compared with the wild-type males. No significant changes could be measured in ERKO females, but there was a trend towards increased bone formation at endosteal bone surfaces.

\section{Serum sex hormone levels}

Analysis of serum sex hormone levels in aged animals showed that E2 concentrations were significantly increased (approximately fivefold) in ERKO females compared with wild-type females (Table 3). In contrast, E2 levels were not altered in male knockouts. Testosterone levels were elevated in both female and male ERKO animals.

\section{Osteoblast activity in vitro}

Since the mineral apposition rate was enhanced and the trabecular bone volume increased in ERKO animals, we next studied the activity of bone cells in vitro.

The primary question was whether ERKO osteoblasts would respond to estrogen or not. Bone marrow cultures were performed using a previously described technique (10- to 12-week-old mice) since it was known that at this age it is possible to isolate sufficient amount of mesenchymal stem cells for cultures (6). Bone marrow cells were first cultured in cell culture flasks for 7 days and after that subcultured in multiwell plates. BMP-4 at $10 \mathrm{ng} / \mathrm{ml}$ was used as a positive control to stimulate osteoblast differentiation. Calcium content of cultures, used as a marker for the mineralization process, was significantly elevated by BMP-4 in both wild-type and ERKO cultures after 14 days in subculture (Fig. 4A and B). Calcium content was also increased in cultures grown in the presence of E2. The specific activity of ALP (i.e. ALP activity per total 
(A)

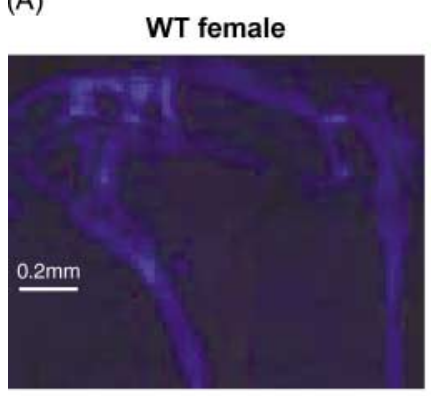

(B)

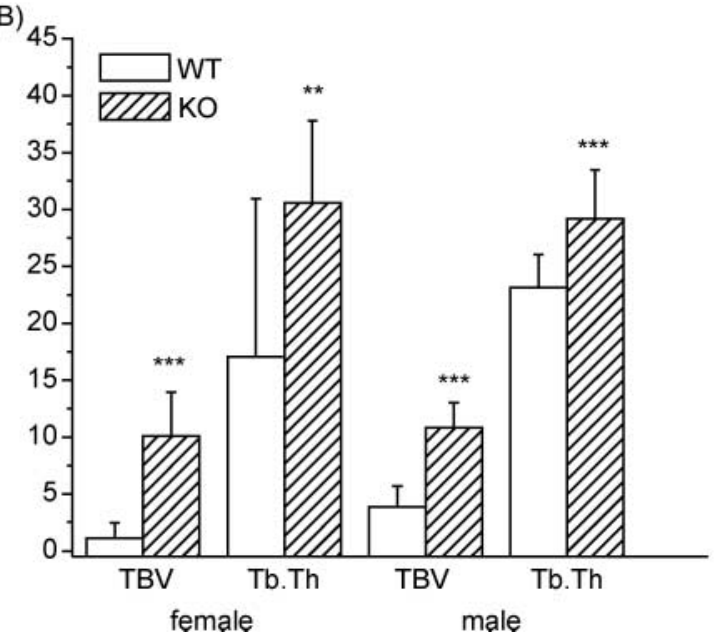

KO female
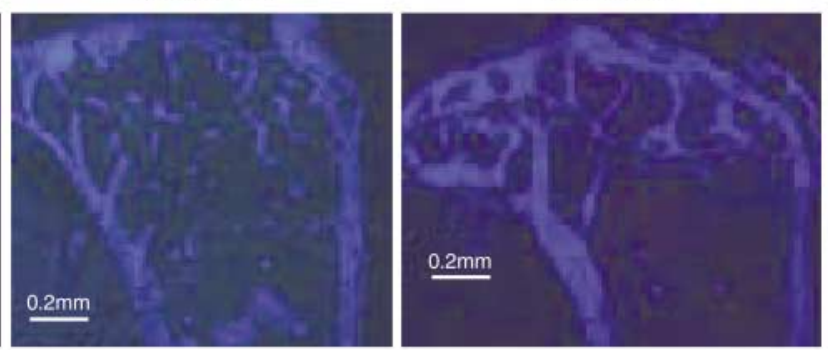

(C)
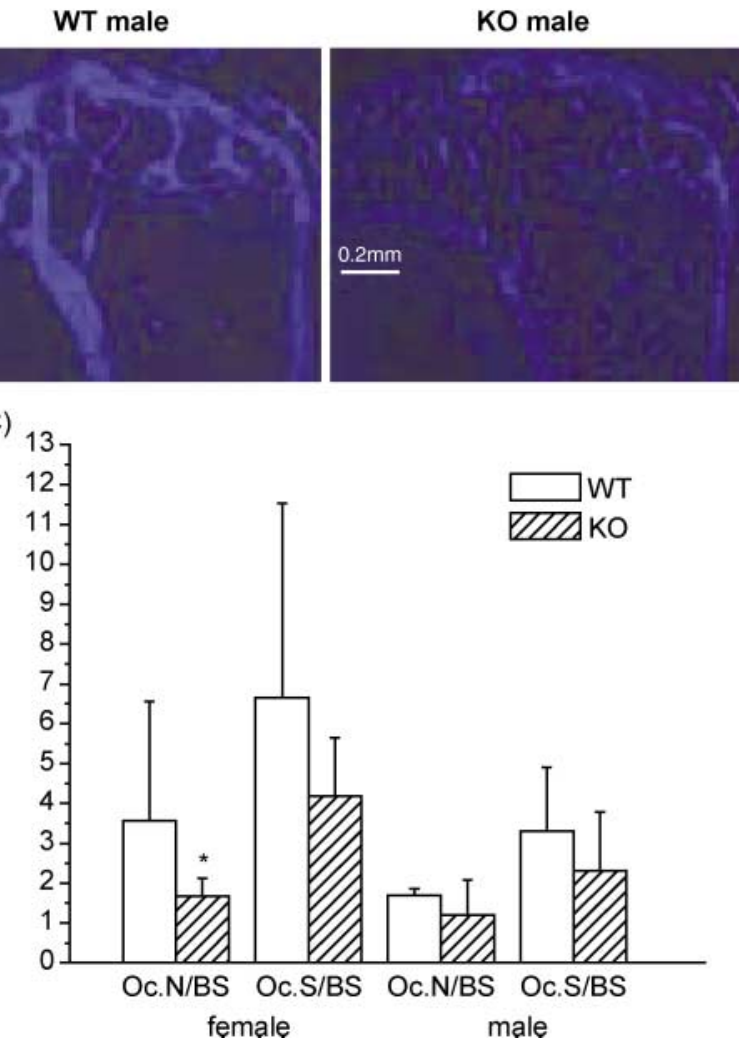

Figure 3 Histomorphometric analysis of trabecular bone of proximal tibia. (A) Longitudinal sections show that ERKO animals have more trabecular bone than their wild-type controls. Note that the growth plate is not detectable in the sample from the ERKO female. (B) Trabecular bone volume (TBV; in \%) and tibial thickness (Tb.Th; in $\mu \mathrm{m}$ ). (C) Number (Oc.N; per mm) and surface area of osteoclasts (Oc.S; in \%) per bone surface (BS). Number of animals per group are the same as for Fig. 1.

Table 2 Bone formation in aged wild-type and ERKO mice.

\begin{tabular}{lcccc}
\hline & WT female & ERKO female & WT male & ERKO male \\
\hline Trabecular bone & & & & \\
MAR $(\mu \mathrm{m} /$ day) & $0.24 \pm 0.12$ & $0.50 \pm 0.04^{\star \star \star}$ & $0.26 \pm 0.12$ & $0.42 \pm 0.11^{\star *}$ \\
BFR/BS $\left(\mu \mathrm{m}^{3} / \mu \mathrm{m}^{2}\right.$ per day) & $0.023 \pm 0.024$ & $0.049 \pm 0.03^{\star}$ & $0.018 \pm 0.019$ & $0.05 \pm 0.07$ \\
BFR/BV $(\% /$ day) & $0.19 \pm 0.18$ & $0.27 \pm 0.21$ & $0.15 \pm 0.16$ & $0.22 \pm 0.23$ \\
BFR/TV $(\% /$ day) & $0.0013 \pm 0.001$ & $0.030 \pm 0.017^{\star \star *}$ & $0.011 \pm 0.013$ & $0.020 \pm 0.021$ \\
Periosteum & $0.31 \pm 0.09$ & $0.32 \pm 0.10$ & $0.37 \pm 0.13$ & $0.47 \pm 0.18$ \\
MAR $(\mu \mathrm{m} /$ day) & $0.08 \pm 0.07$ & $0.10 \pm 0.09$ & $0.12 \pm 0.11$ & $0.22 \pm 0.13^{\star}$ \\
BFR/BS $\left(\mu \mathrm{m}^{3} / \mu \mathrm{m}^{2}\right.$ per day) & $0.012 \pm 0.011$ & $0.016 \pm 0.014$ & $0.018 \pm 0.015$ & $0.033 \pm 0.02^{*}$ \\
BFR/TV $(\% /$ day) & $0.57 \pm 0.09$ & $0.62 \pm 0.10$ & $0.58 \pm 0.16$ & $0.48 \pm 0.19$ \\
Endosteum & $0.12 \pm 0.08$ & $0.19 \pm 0.10$ & $0.21 \pm 0.11$ & $0.13 \pm 0.09^{\star}$ \\
MAR $(\mu \mathrm{m} /$ day) & & & & \\
BFR/BS $\left(\mu \mathrm{m}^{3} / \mu \mathrm{m}^{2}\right.$ per day) & &
\end{tabular}

Bone formation in trabecular bone of proximal tibia and in periosteum and endosteum of femoral shaft. Mineral apposition rate (MAR) and bone formation rate (BFR) are expressed as means \pm S.D. Statistical analysis was performed using Student's $t$-test between wild-type (WT) and knockout females and between wild-type and knockout males. The $P$ values are shown as asterisks. $\left({ }^{\star} P<0.05,{ }^{\star \star} P<0.01,{ }^{\star * \star} P<0.001\right)$. BS, bone surface; BV, bone volume; TV, tissue volume.

protein content) was measured on subculture day 9 from wild-type and knockout mice cultures. Specific ALP activity was increased by $10 \mathrm{pM}$ and $1 \mathrm{nM}$ E2 (Fig. 4C and D). The effect of E2 on calcium and ALP stimulation was similar in female and male mice and thus combined data from female and male cultures are presented. Antiestrogen ICI 182,780 is capable of preventing the stimulatory effect of $\mathrm{E} 2$ in bone nodule assay. This was demonstrated in osteoblast assays when measuring calcium content of the culture (3.6 mmol/l for control, $4.1 \mathrm{mmol} / \mathrm{l}$ for $\mathrm{E} 2,3.4$ for ICI 182,780 and 3.4 for ICI $+\mathrm{E} 2 ; P<0.05$ control vs E2 and for E2 vs ICI + E2). Similar results were obtained in three different cultures. 
Table 3 Serum sex steroid levels in aged wild-type and ERKO mice.

\begin{tabular}{lcccc}
\hline Hormone & WT female & ERKO female & WT male & ERKO male \\
\hline E2 $(\mathrm{pg} / \mathrm{ml})$ & $4.27 \pm 1.84$ & $22.73 \pm 3.45^{\star \star}$ & $2.12 \pm 0.12$ & $2.12 \pm 0.10$ \\
Testosterone $(\mathrm{ng} / \mathrm{ml})$ & $0.23 \pm 0.11$ & $1.82 \pm 0.21^{\star \star \star}$ & $2.80 \pm 0.83$ & $6.34 \pm 1.02^{\star}$ \\
\hline
\end{tabular}

WT, wild-type mice. Data are presented as means \pm S.E. ${ }^{*} P<0.05,{ }^{* \star} P<0.01,{ }^{* * \star} P<0.001$ for WT vs ERKO mice.

To study type I collagen synthesis by osteoblastic cells, PINP concentrations were analyzed from culture media after 3, 6 and 9 days in subculture. After 6 days, both wild-type and ERKO cells were stimulated by E2 and BMP-4 (Fig. 5A). A similar result was obtained after a 9-day culture (data not shown).

However, basal PINP concentrations were much lower in knockout cultures. Figure 5B presents PINP levels from female cultures in each time point. It shows that PINP concentration levels in ERKO cultures do not rise to the same extent as in wild-type cultures.
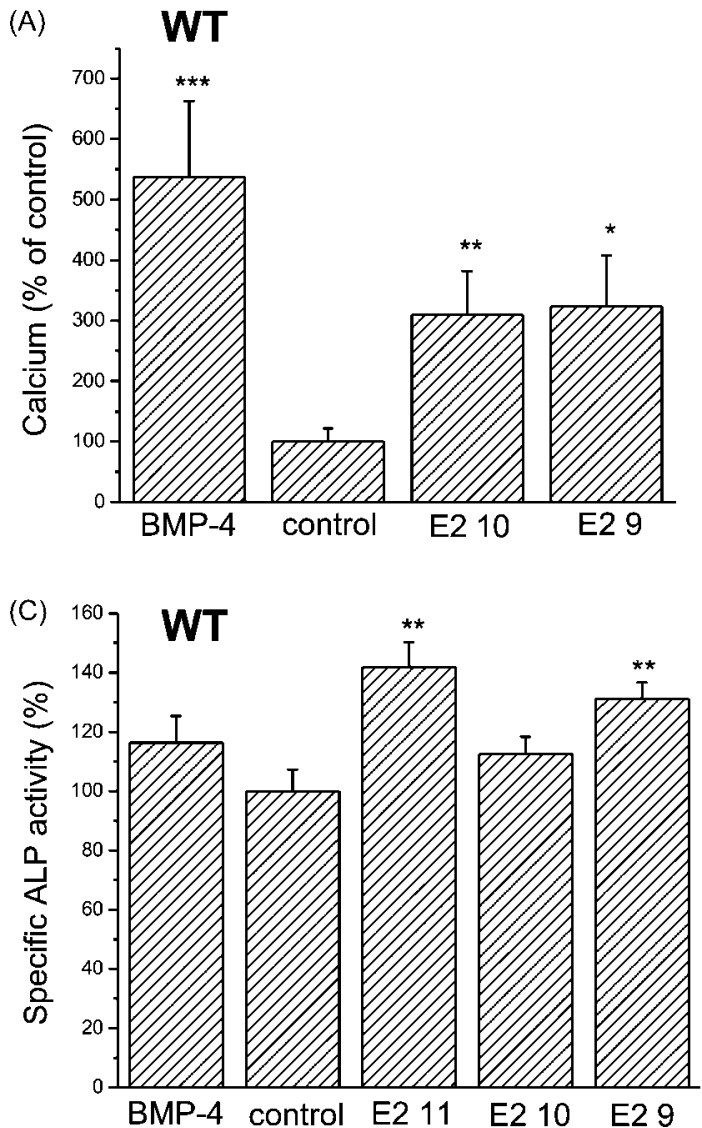

The measurement of total protein content from the same cultures after 9 days shows that total protein level in ERKO mouse cultures was only $35 \pm 4 \%$ of the wild-type value, which could, at least partly, explain the lower PINP levels in knockout mice. When all the culture data were combined, it was demonstrated that the average PINP concentration, as well as total protein content, was indeed significantly lower in knockout cultures compared with wild-type cultures (Fig. 5C). Although total protein content was reduced, ALP levels were not significantly altered in knockout
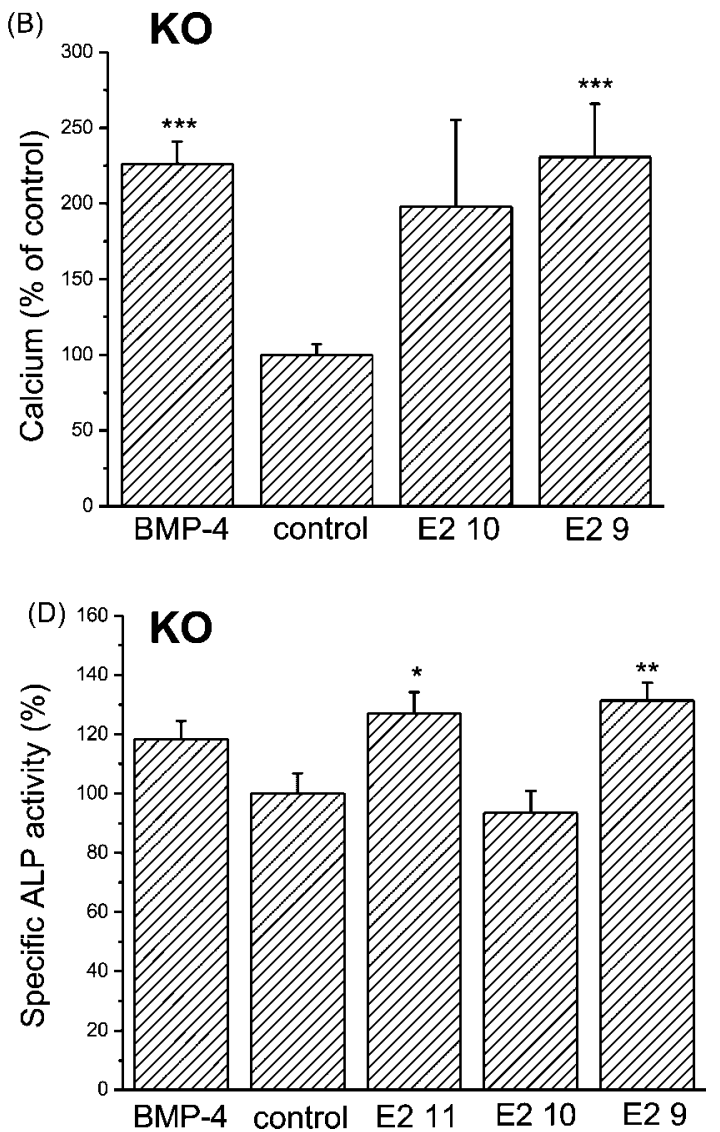

Figure 4 Effect of BMP-4 $(10 \mathrm{ng} / \mathrm{ml})$ and E2 on the calcium content of culture and the specific activity of ALP in mouse bone marrowderived osteoblast cultures. E2 concentrations are expressed as follows: E2 11 (10 pM), E2 10 (100 pM) and E2 9 (1 nM). Calcium content is measured on subculture day 14 from wild-type (A) and ERKO (B) cultures. Specific activity of ALP is determined as ALP activity per total protein concentration and is measured on subculture day 9 from wild-type $(C)$ and ERKO (D) mice cultures. All results (A-D) are combinations of data from female and male cultures, and all the values are presented as a percentage of control. One ERKO and one wild-type mouse were used in each culture and cells were cultured on six parallel wells per group. All the experiments were repeated. Absolute values for ALP controls were $0.35 \pm 0.02$ for wild-type and $0.63 \pm 0.11$ for ERKO mice cultures. Calcium content in control groups were $0.28 \pm 0.09 \mathrm{mM}$ (wild-type) and $0.05 \pm 0.01 \mathrm{mM}$ (ERKO). Values are presented as means \pm S.E.M. The $P$ values from Student's $t$-test between control and other groups are shown as asterisks $\left({ }^{\star} P<0.05,{ }^{\star \star} P<0.01,{ }^{\star * \star} P<0.001\right)$. 
cultures (Fig. 5C). The specific ALP activity was thus even increased, which suggests that differentiation of bone marrow cells to osteoblasts is not disturbed in ERKO animals, although the in vitro proliferation rate might be lower.

\section{Osteoclast resorption cultures}

Histomorphometric analysis revealed that the number of osteoclasts was decreased in aged ERKO females. In order to find out whether ER $\alpha$ deficiency alters osteoclast function, a mixed bone marrow cell population
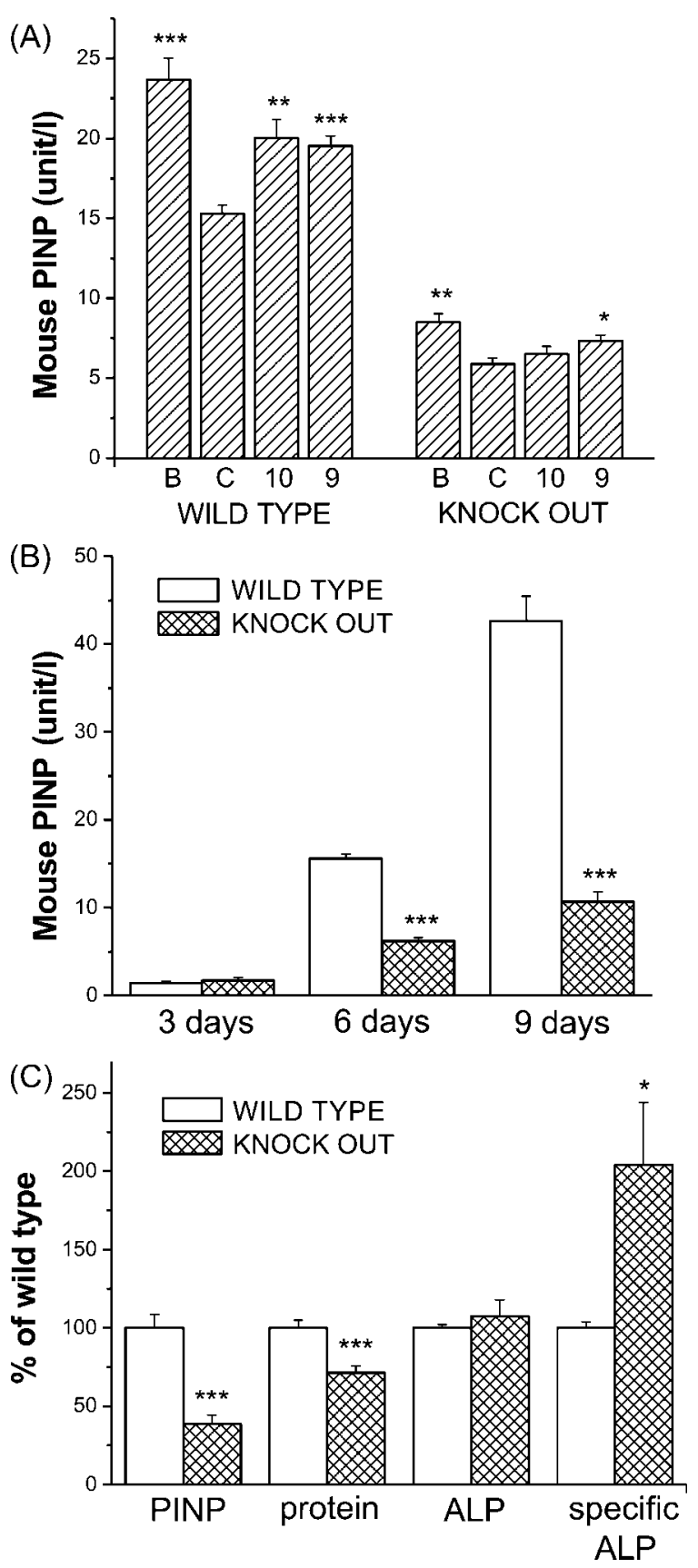

from 2- to 4-day-old mouse pups was cultured on bone slices. The number of osteoclasts (with three or more nuclei) or mono- and binuclear TRACP-positive cells was not significantly different when wild-type and knockout cultures were compared (Fig. 6A). The discrepancy between ex vivo and in vitro results in osteoclast number is not surprising since the age and developmental stage of the animals were totally different. The number of actin rings, resorption pits or nuclei per osteoclast were not significantly altered, either. The appearance of resorption lacunae in knockout mice was also similar to that in wild-type mice (Fig. 6B).

\section{Expression of mRNA for ERB, ERR $\alpha$ and ERR $\gamma$ in bone marrow cells}

RT-PCR of the bone marrow cells showed expression of ER $\beta$ in both wild-type and ERKO animals (Fig. 7A). In addition, all the wild-type and ERKO mouse bone marrow samples tested for the presence of ERR $\alpha$ (Fig. 7B) and ERR $\gamma$ (Fig. 7C) mRNA showed a positive result in RT-PCR. Interestingly, RT-PCR produced stronger bands of ERR $\gamma$ from the bone marrow sample of females than from males in both wild-type and ERKO mice. The possibility of amplification products arising from small amounts of genomic DNA in the isolated RNA was excluded by using mouse genomic DNA template or cDNA reactions without RT enzyme as negative controls in PCR reactions.

\section{Discussion}

Our results demonstrate a statistically significant increase in trabecular bone density, as well as in trabecular bone volume of aged ERKO mice, which is in accordance with previous studies using younger animals (30-32). The changes in trabecular bone were associated with an increase in mineral apposition rate and a slight decrease in the number of osteoclasts in the bone. Serum E2 levels are markedly elevated in female ERKO mice $(28,32)$ and ovariectomized

Figure 5 Analysis of PINP from culture medium. BMP-4 $(10 \mathrm{ng} / \mathrm{ml})$ and E2 had a stimulatory effect on PINP secretion after female cells had been grown for 6 days in subculture (A). Abbreviations are: B, BMP-4; C, control; 10, 100 pM E2; 9, 1 nM E2. Medium background levels have been subtracted from values presented. After 6 and 9 days in subculture, control PINP levels were significantly lower in knockout animal cultures compared with wild-type cultures (B). Combination of data and analysis of all cultures $(n=7)$ revealed that average medium PINP concentration and total protein content of cultures were reduced in knockout animals, whereas ALP activity was unchanged and specific ALP activity (ALP activity per protein content) even significantly increased in knockout animals (C). Values are presented as means \pm S.E.M. The $P$ values from Student's $t$-test between control and other groups $(A)$, or between wild-type and knockout cultures (B and $\mathrm{C})$, are shown as asterisks $\left({ }^{\star} P<0.05,{ }^{\star \star} P<0.01\right.$, $\left.{ }^{\star \star \star} P<0.001\right)$ 


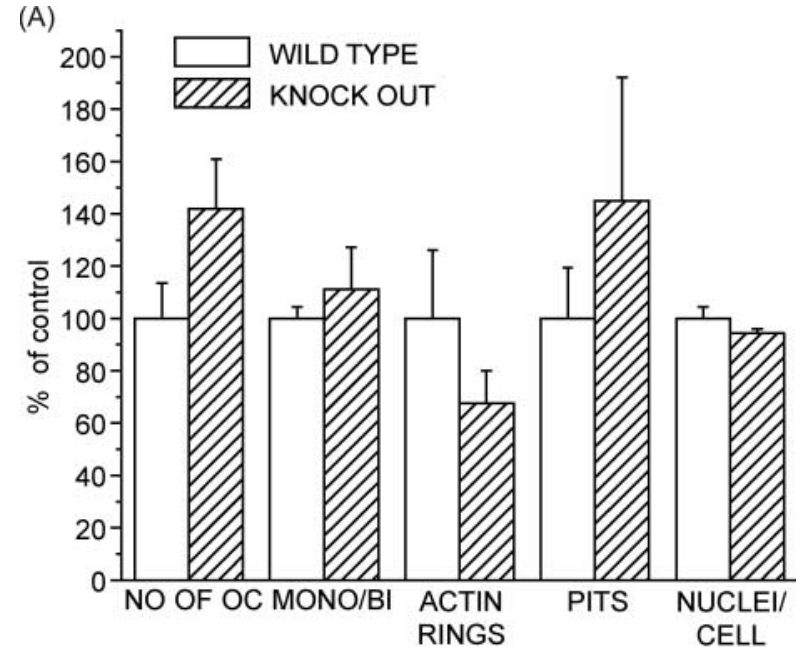

(B)

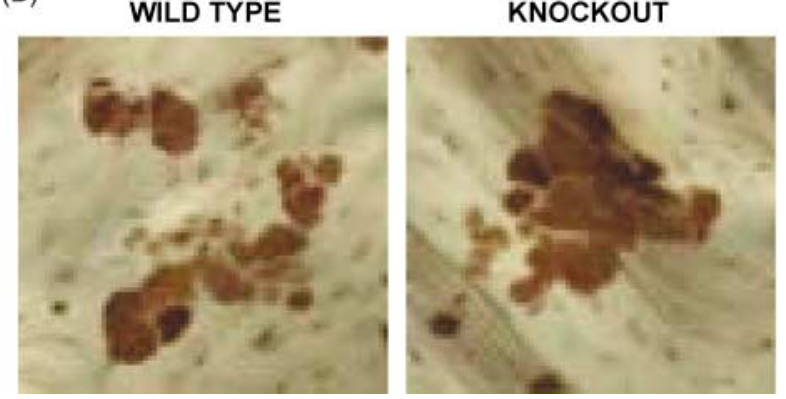

Figure 6 Analysis of ERKO and wild-type osteoclasts cultured on bovine bone slices. The number of osteoclasts (NO OF OC), mono- and binuclear TRACP-positive cells (MONO/BI), actin rings and resorption pits (PITS) per bone slice plus nuclei per osteoclast (NUCLEI/CELL) were counted (A). Images of WGA-lectin stained resorption pits reveals that wild-type and knockout pits look similar (B). Values are presented as means \pm S.E.M. Combined data from 16 cultures of wild-type and 11 cultures of ERKO pups are shown. Student's t-test did not reveal any statistically significant differences between groups.

female ERKO (carrying full knockout of ER $\alpha$ ) mice have recently been shown to respond to E2 treatment (26); these facts suggest a role for ER $\beta$ in maintaining bone mass in females. In males increased trabecular bone volume and bone formation rate are probably associated with the high serum levels of testosterone, since testosterone is capable of maintaining bone volume independently of $\operatorname{ER} \alpha(26,31,33,34)$. Serum testosterone levels are also elevated in female ERKO mice and they have been shown to respond normally to testosterone treatment (26). Furthermore, it has been demonstrated that antiandrogen, but not antiestrogen, treatment reduces the amount of trabecular bone in ERKO females (26) suggesting that the bone phenotype observed in ERKO mice is largely elicited via androgen receptor (AR) in both sexes. Interestingly, the level of AR mRNA is elevated twofold in ERKO females, but not in males (26).

In addition to estrogen and testosterone, serum levels of some peptide hormones such as leptin and IGF-I are markedly altered in ER $\alpha$-deficient mice. After sexual maturation ERKO mice have enhanced serum leptin levels and increased total body fat content (45). This is in accordance with increased body weight in ERKO animals, which is demonstrated in our study and in the study by Lindberg et al. (30). It is also possible that elevated BMD in ERKO mice is, at least partly, a consequence of high leptin levels (46). Serum levels of IGF-I are decreased in ERKO animals $(30,47)$, which might partly explain the decreased bone length. In addition to decreased IGF-I levels, the decrease in bone lengths may be directly associated with high estrogen levels. Crown-rump length of ERKO mice has previously been reported to be normal (47), suggesting decreased bone growth only in the appendicular skeleton. However, our data demonstrate a significant decrease in length of lumbar vertebrae as well.

We also observed that growth plates are fused in bones of old ERKO females, whereas in wild-type females and in bones of ERKO males they are open, as in younger animals. These observations are consistent with recently reported results of Chagin et al. (48). This together with the reduced length of bones suggests that bone maturation and growth plate closure are induced or accelerated by ER $\beta$ in the presence of high E2 in female ERKO mice. ER $\alpha$ and ER $\beta$ are both expressed especially in the proliferation zone of the growth plate in human and rodents (49). However, lack of functional ER $\alpha$ in a 28-year-old man has been reported to result in severe osteoporosis and incomplete epiphyseal closure (23), which is opposite to our results with ER $\alpha$ knockout mice. However, diagnosis of osteoporosis in this case as well as in aromatase-deficient patients, has been strongly criticized (50). An increased rate of remodeling in these subjects has been suggested to be due to the fact that they do not reach skeletal maturity. Hence, an increased rate of remodeling in these patients, unlike in the mature skeleton where it is caused by a decrease of estrogens or androgen steroids, would be physiologic and appropriate. Differences in epihyseal plate maturation between ERKO animals and Era-deficient man are most obviously due to species differences in regulation of growth plate closure as is also seen in normal mice. Interestingly, serum IGF-I levels were elevated in Er $\alpha$-deficient man (23), while decreased in ERKO animals.

Although full-length ER $\alpha$ is not present in our ERKO animals, expression of an ER $\alpha$ splicing variant has been reported at least in uterus (51) and bone (33). A corresponding $46 \mathrm{kDa}$ isoform of $\mathrm{ER} \alpha$ lacking the $\mathrm{N}$-terminal activating function-1 (AF-1) domain has also been detected in human tissues including primary osteoblasts, as well as in bones of ERKO mice (52). This isoform can bind E2 and DNA and transactivate target genes via the AF-2 domain, but its importance in bone function remains unclear. However, neither bones of male mice carrying a total ER $\alpha$ knockout (26) nor male ERKO mice expressing the N-truncated 


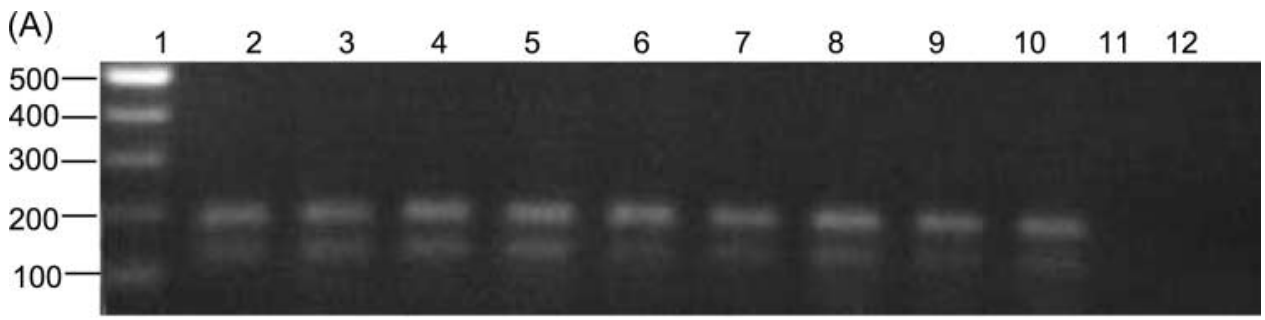

(B)
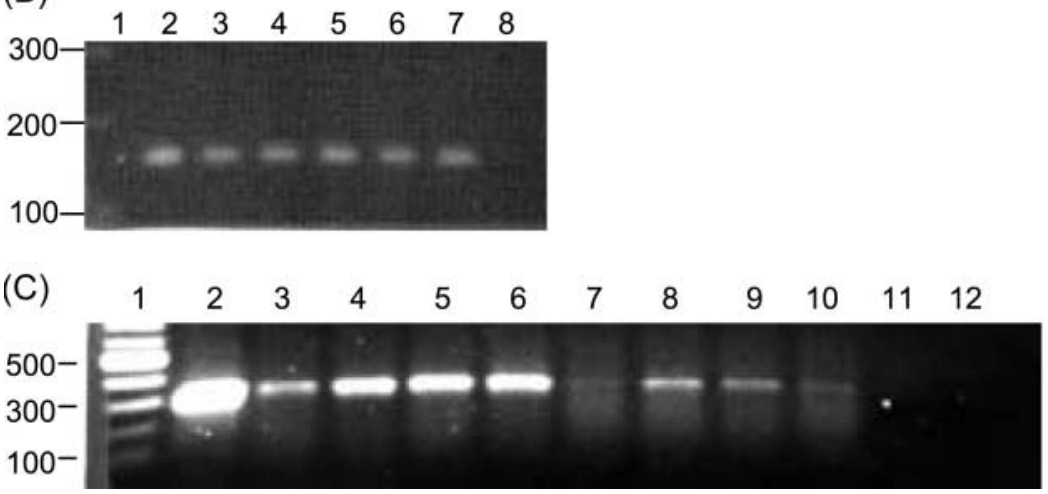

Figure 7 RT-PCR demonstration of expression of mRNA for ER $\beta$, ERR $\alpha$ and ERR $\gamma$ in bone marrow. (A) ER $\beta$ RT-PCR products on the agarose gel: lane 1, $100 \mathrm{bp}$ ladder; lane 2, positive control (ventral prostate of wild-type mouse); lanes 3 and 4, wild-type female bone marrows; lanes 5 and 6, ERKO female bone marrows; lanes 7 and 8, WT male bone marrows; lanes 9 and 10, ERKO male bone marrows; lane 11, genomic DNA; and lane 12, blank. Expected PCR product size: $187 \mathrm{bp}$ (upper band). (B) ERR $\alpha$ RT-PCR products on the agarose gel: lane 1, $100 \mathrm{bp}$ ladder; lane 2, positive control (wild-type kidney); lane 3, ERKO female bone marrow; lanes 4 and 5, wildtype female bone marrows; lane 6, ERKO male bone marrow; lane 7, WT male bone marrow; lane 8, blank. Expected PCR product size: 153 bp. (C) ERR $\gamma$ RT-PCR products on the agarose gel: lane 1, 100 bp ladder; lane 2, positive control (kidney); lanes 3 and 4, wild-type female bone marrow samples; lanes 5 and 6, ERKO female bone marrows; lanes 7 and 8, wild-type male bone marrows; lanes 9 and 10, ERKO female bone marrows; lane 11, blank; lane 12, genomic DNA. Expected PCR product size: 275 bp.

$\mathrm{ER} \alpha$ isoform (31-33) responded to E2 administration in vivo. This suggests that the full-length $\mathrm{ER} \alpha$ possessing AF-1 is required for most of the effects of E2 on mouse bones.

In vitro results are of special interest since no corresponding experiments have been reported previously. An obvious advantage of the in vitro model is the exclusion of systemic factors other than those of interest. Only one in vitro experiment with ERKO bone cells has been described previously (53). It reported differentiation of ERKO calvarial cells to osteoblastic cells, which formed mineralized nodules. We show here that E2 is capable of stimulating osteogenic differentiation of bone marrow cells derived from both male and female mice even in the absence of ER $\alpha$. This was demonstrated by increased synthesis of type 1 collagen, increased ALP activity and increased accumulation of calcium in mineralizing bone nodules in cultures. These results suggest that the N-terminal-truncated ER $\alpha$ isoform, ER $\beta$ or another yet unknown ER mediates the effects of E2 on osteoblast differentiation of ERKO bone marrow cells. Previous experiments with knockout mice have shown that ER $\beta$ female knockout mice exhibit a higher bone mineral content or bone mineral density compared with control animals and the E2induced increase in bone formation in $\mathrm{ER} \beta^{-/-}$mice is equivalent to the increase in wild-type animals (32, 54-57). Taken together, the previous experiments with ER $\alpha$ and ER $\beta$ knockout mice suggest that ER $\beta$ plays a minor role in bone metabolism whereas ER $\alpha$ has been shown to have an important role in the mediation of estrogen effects in the skeleton $(26,34$, 36). We describe a stimulatory effect of E2 in ERKO bone cells, but further experiments are needed to learn how E2 stimulates bone formation in ERKO animals. The fact that the pure antiestrogen ICI 182,780 opposed the stimulatory effect of E2 suggests that this is ER mediated. One possibility is that the ERRs are also involved since at least $\mathrm{ERR} \alpha$ is known to regulate bone formation in calvarial cultures (58). As demonstrated in this work, the orphan receptors ERR $\alpha$ and ERR $\gamma$ are expressed in the bone marrow of ERKO as well as wild-type mice. It is possible that these ERRs mediate or modulate effects of E2-activated ER $\beta$ (59).

Despite a response of ERKO osteoblasts to E2, we found that the total protein content of cultures was markedly lower in ERKO than in wild-type cultures. One possible explanation for a difference between the groups might be an increased apoptosis rate of ERKO cells. However, it is more probable that cell proliferation is slowed down in the absence of ER $\alpha$. This could be caused by altered interactions of ERR $\alpha$ or $\gamma$, or the 
inability of the N-terminal-truncated ER $\alpha$ isoform to respond to growth factor-elicited stimuli. Several growth factors have been shown to cause ligand-independent activation of ERs via the mitogen-activated protein kinase (MAPK) pathway $(60,61)$. These estrogen-independent ER activation mechanisms have been recently demonstrated to be present in particular in non-reproductive tissues, such as bone (62). Bone cells produce different growth factors and FCS used in the culture mediums also contains them. It is thus possible that these factors stimulate cell proliferation especially in wild-type cultures where $\mathrm{ER} \alpha$ is present. Whether reduced PINP levels in ERKO animals are a consequence of decreased protein levels or due to specific inhibition in collagen synthesis remains questionable. However, matrix maturation and mineralization phases occurred normally in ERKO cells, and specific ALP activity was even higher in ERKO cells compared with wild-type cells.

An interesting question is why the stimulatory effect of E2 has not been demonstrated in the in vivo experiments with ERKO males $(26,31,33,34)$, although E2 stimulates osteoblasts in vitro as shown here. One explanation for this discrepancy may be that the in vivo effects are much more complicated than those in the in vitro conditions. Osteoblasts and osteoclasts, for example, continuously communicate with each other and with other cells in the in vivo situation. Another reason may be that only trabecular bone parameters have been measured in several studies. Vandenput et al. (31) have provided an interesting report showing that although estrogen treatment did not prevent trabecular bone loss in orchidectomized ERKO mice, it stimulated bone formation at the endocortical bone surface suggesting that osteoblasts may respond to estrogen in the absence of $E R \alpha$.

To summarize, we demonstrate in this work that E2 is able to stimulate osteoblastic differentiation and function in vitro in bone marrow cultures of $\mathrm{ER} \alpha$ deficient female and male mice. In vivo, aged ERKO animals were shown to have increased trabecular bone volume, which was associated with an enhanced rate of bone formation and a decreased number of osteoclasts. ERKO animals had shorter bones and, interestingly, growth plates were fused in aged ERKO females, although they were open in ERKO males and wildtype mice. These results suggest that ER $\beta$-mediated or non-receptor-mediated mechanisms are involved in E2 stimulation of bone formation even in the absence of the full-length $\mathrm{ER} \alpha$.

\section{Acknowledgements}

We thank Dr Kenneth Korach for kindly providing the ERKO mice. We also thank Soili Jussila for skilful technical assistance and animal care. The Turku Graduate School of Biomedical Sciences (V P), the Finnish
Medical Foundation (V P), the Academy of Finland $(\mathrm{H} \mathrm{K} \mathrm{V}$ and $\mathrm{P} \mathrm{H})$ and Schering $\mathrm{AG}(\mathrm{H} \mathrm{K} \mathrm{V}$ and $\mathrm{P} \mathrm{H})$ have supported this study.

\section{References}

1 Morishima A, Grumbach MM, Simpson ER, Fisher C \& Qin K. Aromatase deficiency in male and female siblings caused by a novel mutation and the physiological role of estrogens. Journal of Clinical Endocrinology and Metabolism $1995 \mathbf{8 0} 3689-3698$.

2 Carani C, Qin K, Simoni M, Faustini-Fustini M, Serpente S, Boyd J, Korach KS \& Simpson ER. Effect of testosterone and estradiol in a man with aromatase deficiency. New England Journal of Medicine $199733791-95$.

3 Öz OK, Zerwekh JE, Fisher C, Graves K, Nanu L, Millsaps R \& Simpson ER. Bone has a sexually dimorphic response to aromatase deficiency. Journal of Bone and Mineral Research 200015 507-514.

4 Miyaura C, Toda K, Inada M, Ohshiba T, Matsumoto C, Okada T, Ito M, Shizuta Y \& Ito A. Sex- and age-related response to aromatase deficiency in bone. Biochemical and Biophysical Research Communications $20012 \mathbf{2 8 0} 1062-1068$.

5 Vanderschueren D, Boonen S, Ederveen AG, de Coster R, Van Herck E, Moermans K, Vandenput L, Verstuyf A \& Bouillon R. Skeletal effects of estrogen deficiency as induced by an aromatase inhibitor in an aged male rat model. Bone 200027 611-617.

6 Qu Q, Perälä-Heape M, Kapanen A, Dahllund J, Salo J, Väänänen HK \& Härkönen P. Estrogen enhances differentiation of osteoblasts in mouse bone marrow culture. Bone 199822 201-209.

7 Zhou S, Zilberman Y, Wassermann K, Bain SD, Sadovsky Y \& Gazit D. Estrogen modulates estrogen receptor alpha and beta expression, osteogenic activity, and apoptosis in mesenchymal stem cells (MSCs) of osteoporotic mice. Journal of Cellular Biochemistry $2001 \mathbf{8 1} 144-155$.

8 Gohel A, McCarthy MB \& Gronowicz G. Estrogen prevents glucocorticoid-induced apoptosis in osteoblasts in vivo and in vitro. Endocrinology $19991405339-5347$.

9 Kousteni S, Bellido T, Plotkin LI, O’Brien CA, Bodenner DL, Han L, Han K, DiGregorio GB, Katzenellenbogen JA, Katzenellenbogen BS, Roberson PK, Weinstein RS, Jilka RL \& Manolagas SC. Nongenotropic, sex-nonspecific signaling through the estrogen or androgen receptors: dissociation from transcriptional activity. Cell $2001 \mathbf{1 0 4}$ 719-730.

10 Jilka RL, Hangoc G, Girasole G, Passeri G, Williams DC, Abrams JS, Boyce B, Broxmeyer H \& Manolagas SC. Increased osteoclast development after estrogen loss: mediation by interleukin-6. Science $199225788-91$.

11 Srivastava S, Toraldo G, Weitzmann MN, Cenci S, Ross FP \& Pacifici R. Estrogen decreases osteoclast formation by down-regulating receptor activator of NF-kappa B ligand (RANKL)-induced JNK activation. Journal of Biological Chemistry $2001 \mathbf{2 7 6}$ 8836-8840.

12 Parikka V, Lehenkari P, Sassi ML, Halleen J, Risteli J, Härkönen P \& Väänänen HK. Estrogen reduces the depth of resorption pits by disturbing the organic bone matrix degradation activity of mature osteoclasts. Endocrinology $20011425371-5378$.

13 Bord S, Vedi S, Beavan SR, Horner A \& Compston JE. Megakaryocyte population in human bone marrow increases with estrogen treatment: a role in bone remodeling? Bone 200027 397-401.

14 Ramalho AC, Couttet P, Baudoin C, Morieux C, Graulet AM, de Vernejoul MC \& Cohen-Solal ME. Estradiol and raloxifene decrease the formation of multinucleate cells in human bone marrow cultures. European Cytokine News 200213 39-45.

15 Eriksen EF, Colvard DS, Berg NJ, Graham ML, Mann KG, Spelsberg TC \& Riggs BL. Evidence of estrogen receptors in normal human osteoblast-like cells. Science $1988 \mathbf{2 4 1} 84-86$.

16 Komm BS, Terpening CM, Benz DJ, Graeme KA, Gallegos A, Korc M, Greene GL, O’Malley BW \& Haussler MR. Estrogen 
binding, receptor mRNA, and biologic response in osteoblast-like osteosarcoma cells. Science $1988 \mathbf{2 4 1} 81-84$.

17 Onoe Y, Miyaura C, Ohta H, Nozawa S \& Suda T. Expression of estrogen receptor beta in rat bone. Endocrinology $1997 \mathbf{1 3 8}$ 4509-4512.

18 Pensler JM, Radosevich JA, Higbee R \& Langman CB. Osteoclasts isolated from membranous bone in children exhibit nuclear estrogen and progesterone receptors. Journal of Bone and Mineral Research 19905 797-802.

19 Oursler MJ, Osdoby P, Pyfferoen J, Riggs BL \& Spelsberg TC. Avian osteoclasts as estrogen target cells. PNAS $1991 \mathbf{8 8}$ 6613-6617.

20 Huang WH, Lau AT, Daniels LL, Fujii H, Seydel U, Wood DJ, Papadimitriou JM \& Zheng MH. Detection of estrogen receptor alpha, carbonic anhydrase II and tartrate-resistant acid phosphatase mRNAs in putative mononuclear osteoclast precursor cells of neonatal rats by fluorescence in situ hybridization. Journal of Molecular Endocrinology $199820211-219$.

21 Oreffo RO, Kusec V, Virdi AS, Flanagan AM, Grano M, ZamboninZallone A \& Triffitt JT. Expression of estrogen receptor-alpha in cells of the osteoclastic lineage. Histochemistry and Cell Biology $1999111125-133$.

22 Collier FM, Huang WH, Holloway WR, Hodge JM, Gillespie MT, Daniels LL, Zheng MH \& Nicholson GC. Osteoclasts from human giant cell tumors of bone lack estrogen receptors. Endocrinology $19981391258-1267$.

23 Smith EP, Boyd J, Frank GR, Takahashi H, Cohen RM, Specker B, Williams TC, Lubahn D \& Korach KS. Estrogen resistance caused by a mutation in the estrogen-receptor gene in a man. New England Journal of Medicine 1994331 1056-1061.

24 Dieudonne SC, Xu T, Chou JY, Kuznetsov SA, Satomura K, Mankani M, Fedarko NS, Smith EP, Robey PG \& Young MF. Immortalization and characterization of bone marrow stromal fibroblasts from a patient with a loss of function mutation in the estrogen receptor-alpha gene. Journal of Bone and Mineral Research 199813 598-608.

25 Lindberg MK, Weihua Z, Andersson N, Moverare S, Gao H, Vidal O, Erlandsson M, Windahl S, Andersson G, Lubahn DB, Carlsten H, Dahlman-Wright K, Gustafsson JA \& Ohlsson C. Estrogen receptor specificity for the effects of estrogen in ovariectomized mice. Journal of Endocrinology $2002 \mathbf{1 7 4}$ $167-178$.

26 Sims NA, Clement-Lacroix P, Minet D, Fraslon-Vanhulle C, Gaillard-Kelly M, Resche-Rigon M \& Baron R. A functional androgen receptor is not sufficient to allow estradiol to protect bone after gonadectomy in estradiol receptor-deficient mice. Journal of Clinical Investigation $2003 \mathbf{1 1 1} 1319-1327$.

27 Lubahn DB, Moyer JS, Golding TS, Couse JF, Korach KS \& Smithies O. Alteration of reproductive function but not prenatal sexual development after insertional disruption of the mouse estrogen receptor gene. PNAS $19939011162-11166$.

28 Couse JF \& Korach KS. Estrogen receptor null mice: what have we learned and where will they lead us? Endocrine Reviews 199920 358-417.

29 Wronski TJ, Lowry PL, Walsh CC \& Ignaszewski LA. Skeletal alterations in ovariectomized rats. Calcified Tissue International $198537324-328$.

30 Lindberg MK, Alatalo SL, Halleen JM, Mohan S, Gustafsson JA \& Ohlsson C. Estrogen receptor specificity in the regulation of the skeleton in female mice. Journal of Endocrinology $2001 \mathbf{1 7 1}$ 229-236.

31 Vandenput L, Ederveen AG, Erben RG, Stahr K, Swinnen JV, Van Herck E, Verstuyf A, Boonen S, Bouillon R \& Vanderschueren D. Testosterone prevents orchidectomy-induced bone loss in estrogen receptor-alpha knockout mice. Biochemical and Biophysical Research Communications 2001285 70-76.

32 Sims NA, Dupont S, Krust A, Clement-Lacroix P, Minet D, Resche-Rigon M, Gaillard-Kelly M \& Baron R. Deletion of estrogen receptors reveals a regulatory role for estrogen receptors-beta in bone remodeling in females but not in males. Bone $2002 \mathbf{3 0}$ $18-25$.

33 McDougall KE, Perry MJ, Gibson RL, Colley SM, Korach KS \& Tobias JH. Estrogen receptor-alpha dependency of estrogen's stimulatory action on cancellous bone formation in male mice. Endocrinology 2003144 1994-1999.

34 Lindberg MK, Moverare S, Skrtic S, Alatalo S, Halleen J, Mohan S, Gustafsson JA \& Ohlsson C. Two different pathways for the maintenance of trabecular bone in adult male mice. Journal of Bone and Mineral Research 200217 555-562.

35 Lee K, Jessop H, Suswillo R, Zaman G \& Lanyon L. Endocrinology: bone adaptation requires oestrogen receptor-alpha. Nature 2003 424389.

36 Vidal O, Lindberg MK, Hollberg K, Baylink DJ, Andersson G, Lubahn DB, Mohan S, Gustafsson JA \& Ohlsson C. Estrogen receptor specificity in the regulation of skeletal growth and maturation in male mice. PNAS 200097 5474-5479.

37 Peng Z, Tuukkanen J, Zhang H, Jämsä T \& Väänänen HK. The mechanical strength of bone in different rat model of experimental osteoporosis. Bone 199415 523-532.

38 Parfitt AM, Drezner MK, Glorieux FH, Kanis JA, Malluche H, Meunier PJ, Ott SM \& Recker RR. Bone histomorphometry: standardization of nomenclature, symbols, and units. Report of the ASBMR Histomorphometry Nomenclature Committee. Journal of Bone and Mineral Research 19872 595-610.

39 Rulli SB, Kuorelahti A, Karaer O, Pelliniemi LJ, Poutanen M \& Huhtaniemi I. Reproductive disturbances, pituitary lactotrope adenomas, and mammary gland tumors in transgenic female mice producing high levels of human chorionic gonadotropin. Endocrinology $2002 \mathbf{1 4 3} 4084-4095$.

40 Boyde A, Ali NN \& Jones SJ. Resorption of dentine by isolated osteoclasts in vitro. British Dental Journal 1984156 216-220.

41 Chambers TJ, Revell PA, Fuller K \& Athanasou NA. Resorption of bone by isolated rabbit osteoclasts. Journal of Cell Science $1984 \mathbf{6 6}$ 383-399.

42 Lakkakorpi P, Tuukkanen J, Hentunen T, Järvelin K \& Väänänen K. Organization of osteoclast microfilaments during the attachment to bone surface in vitro. Journal of Bone and Mineral Research 1989 $4817-825$.

43 Selander K, Lehenkari P \& Väänänen HK. The effects of bisphosphonates on the resorption cycle of isolated osteoclasts. Calcified Tissue International $199455368-375$.

44 Chomczynsky P \& Sacchi N. Single-step method of RNA isolation by acid guanidium-thiocyanate-phenol-chloroform extraction. Analytical Biochemistry 1987162 156-159.

45 Ohlsson C, Hellberg N, Parini P, Vidal O, Bohlooly M, Rudling M, Lindberg MK, Warner M, Angelin B \& Gustafsson JA. Obesity and disturbed lipoprotein profile in estrogen receptor-alpha-deficient male mice. Biochemical and Biophysical Research Communications 2000278 640-645.

46 Whipple T, Sharkey N, Demers L \& Williams N. Leptin and the skeleton. Clinical Endocrinology 200257 701-711.

47 Vidal O, Lindberg M, Savendahl L, Lubahn DB, Ritzen EM, Gustafsson JA \& Ohlsson C. Disproportional body growth in female estrogen receptor-alpha-inactivated mice. Biochemical and Biophysical Research Communications 1999265 569-571.

48 Chagin AS, Lindberg MK, Andersson N, Moverare S, Gustafsson JA, Savendahl L \& Ohlsson C. Estrogen receptor-beta inhibits skeletal growth and has the capacity to mediate growth plate fusion in female mice. Journal of Bone and Mineral Research $20041972-77$.

49 van der Eerden BC, Karperien M \& Wit JM. Systemic and local regulation of the growth plate. Endocrine Reviews $2003 \mathbf{2 4}$ 782-801.

50 Manolagas SC, Kousteni S \& Jilka RL. Sex steroids and bone. Recent Progress in Hormone Research 200257 385-409.

51 Couse JF, Curtis SW, Washburn TF, Lindzey J, Golding TS, Lubahn DB, Smithies O \& Korach KS. Analysis of transcription and estrogen insensitivity in the female mouse after targeted 
disruption of the estrogen receptor gene. Molecular Endocrinology $199591441-1454$.

52 Denger S, Reid G, Kos M, Flouriot G, Parsch D, Brand H, Korach KS Sonntag-Buck V \& Gannon F. ERalpha gene expression in human primary osteoblasts: evidence for the expression of two receptor proteins. Molecular Endocrinology 200115 2064-2077.

53 McCauley LK, Tozum TF, Kozloff KM, Koh-Paige AJ, Chen C, Demashkieh M, Cronovich H, Richard V, Keller ET, Rosol TJ \& Goldstein SA. Transgenic models of metabolic bone disease: impact of estrogen receptor deficiency on skeletal metabolism. Connective Tissue Research $2003 \mathbf{4 4} 250-263$.

54 McDougall KE, Perry MJ, Gibson RL, Bright JM, Colley SM, Hodgin JB, Smithies O \& Tobias JH. Estrogen-induced osteogenesis in intact female mice lacking ERbeta. American Journal of Physiology. Endocrinology and Metabolism 2002283 E817-E823.

55 Windahl SH, Vidal O, Andersson G, Gustafsson JÅ \& Ohlsson C. Increased cortical bone mineral content but unchanged trabecular bone mineral density in female ERbeta $(-/-)$ mice. Journal of Clinical Investigation 1999104 895-901.

56 Windahl SH, Hollberg K, Vidal O, Gustafsson JÅ, Ohlsson C \& Andersson G. Female estrogen receptor beta $-/-$ mice are partially protected against age-related trabecular bone loss. Journal of Bone and Mineral Research 200116 1388-1398.

57 Ke HZ, Qi H, Crawford DT, Simmons HA, Zhang Q, Brown TA, Petersen DN, Jee WSS \& Thompson DD. Improved survival rate and bone status in senile female mice lacking estrogen receptorbeta. Journal Bone and Mineral Res 200217 (suppl.) S133.

58 Bonnelye E, Merdad L, Kung V \& Aubin JE. The orphan nuclear estrogen receptor-related receptor alpha (ERRalpha) is expressed throughout osteoblast differentiation and regulates bone formation in vitro. Journal of Cell Biology 2001153 971-984.

59 Giguere V. To ERR in the estrogen pathway. Trends in Endocrinology and Metabolism $200213220-225$.

60 Kato S, Endoh H, Masuhiro Y, Kitamoto T, Uchiyama S, Sasaki H, Masushige S, Gotoh Y, Nishida E, Kawashima H, Metzger D \& Chambon P. Activation of the estrogen receptor through phosphorylation by mitogen-activated protein kinase. Science 1995 $2701491-1494$.

61 Lee AV, Cui X \& Oesterreich S. Cross-talk among estrogen receptor, epidermal growth factor, and insulin-like growth factor signaling in breast cancer. Clinical Cancer Research 20017 4429S-4435S.

62 Ciana P, Raviscioni M, Mussi P, Vegeto E, Que I, Parker MG, Lowik C \& Maggi A. In vivo imaging of transcriptionally active estrogen receptors. Nature Medicine 2003 9 82-86.

Received 22 July 2004

Accepted 18 October 2004 